\title{
Acidity characterization of rare-earth-exchanged $Y$ zeolite using 31P MAS NMR
}

\author{
Shanqing $\mathrm{Yu}^{*}$, Huiping Tian \\ Research Institute of Petroleum Processing, SINOPEC, Beijing 100083, China
}

\section{A R T I C L E I N F O}

Article history:

Received 30 March 2014

Accepted 13 May 2014

Published 20 August 2014

\section{Keywords:}

Y zeolite

Rare earth

Acid site

Solid-state ${ }^{31}$ P NMR

\begin{abstract}
A B S T R A C T
Detailed qualitative and quantitative information on the effects of rare-earth (RE) cations on the types (Brönsted and Lewis), strengths, and distributions of acid sites on Y zeolite was studied by solid-state ${ }^{31} \mathrm{P}$ magic-angle spinning nuclear magnetic resonance (MAS NMR) spectroscopy, using adsorbed trimethylphosphine oxide (TMPO) and tributylphosphine oxide (TBPO) as probe molecules. A total of seven ${ }^{31} \mathrm{P}$ resonance peaks, with ${ }^{31} \mathrm{P}$ NMR/TMPO chemical shifts at $\delta=78,70,65,62$, 58,55 , and 53 , corresponding to sites with different acid strengths, were identified. The peaks at $\delta=$ 78 and 70 arose from external and internal acid sites, the peaks at $\delta=65,62,58$, and 53 were from internal Brönsted acid sites, and the peak at $\delta=55$ was from internal Lewis acid sites. With increasing RE content, the number of medium strength Brönsted acid sites ( $\delta=62$ and 58) increased significantly, whereas those of strong Brönsted acid sites $(\delta=65)$ and weak Lewis acid sites $(\delta=55)$ decreased. These experimental results were explained in terms of the influence of framework Al, extra-framework $\mathrm{Al}$, and $\mathrm{RE}$ cations on the $\mathrm{Y}$ zeolite acidity.
\end{abstract}

(C) 2014, Dalian Institute of Chemical Physics, Chinese Academy of Sciences. Published by Elsevier B.V. All rights reserved.

\section{Introduction}

Rare-earth-cation-exchanged Y zeolites (REHY) are important because they are fluid catalytic cracking catalysts with superior catalytic properties such as high stability and activity [1-3]. It has been reported that the stability of zeolite can be improved by the addition of RE cations, principally those from the light group (La, Ce, Nd, Sm, and Pr) [3,4]. This effect has been attributed to the formation of hydroxy RE cationic species within zeolite channels. Another important role of RE cations is the modification of Y zeolite acidity. Richardson [5] investigated the high catalytic activity of a cation-exchanged zeolite and observed that the bond strength of Brönsted (B) $\mathrm{OH}$ groups was perturbed by the polarizing effect of neighboring cations. Ward [6] explained the generation of B acidity based on the dissociation of adsorbed water molecules by electrostatic fields around RE cations. It is therefore necessary to obtain detailed information on the types, strengths, concentrations, and locations of acid sites on REHY zeolites to understand the detailed reaction mechanisms and related catalytic features of the catalysts.

The acidity of REHY zeolites has been widely investigated using conventional methods such as temperature-programmed desorption (TPD), infrared spectroscopy (IR), and nuclear magnetic resonance ( ${ }^{1} \mathrm{H}$ NMR) spectroscopy of adsorbed basic probe molecules [7-9]. Although these conventional methods are useful in providing qualitative and quantitative information (e.g., acid types and amounts) on acid sites, most techniques cannot provide detailed acidity information.

Recently, a novel solid-state ${ }^{31} \mathrm{P}$ NMR technique was used

\footnotetext{
*Corresponding author. Tel: +86-10-82368972; Fax: +86-10-62311290; E-mail: yusq.ripp@sinopec.com This work was supported by the National Basic Research Program of China (973 Program, 2003CB615804), the National Natural Science Foundation of China (20673054), and the National Key Technology R\&D Program (2012BAE05B00).

DOI: 10.1016/S1872-2067(14)60149-2 | http://www.sciencedirect.com/science/journal/18722067 | Chin. J. Catal., Vol. 35, No. 8, August 2014
} 
for simultaneous qualitative and quantitative investigation of acidic properties using trimethylphosphine oxide (TMPO) and tributylphosphine oxide (TBPO) [10]. Unlike TBPO (kinetic diameter ca. $0.82 \mathrm{~nm}$ ), which can only be adsorbed on the external surfaces of Y zeolite, TMPO (ca. $0.55 \mathrm{~nm}$ ) can enter the zeolite channels, enabling simultaneous detection of internal and external acid sites. In addition, quantitative information on the acid sites (i.e., the acid concentration) can be obtained when ${ }^{31} \mathrm{P}$ NMR experiments are performed in conjunction with elemental analysis by inductively coupled plasma-mass spectrometry (ICP-MS).

In this study, the properties of acid sites, namely their types, locations, concentrations, and strengths on a REHY zeolite, were investigated in detail using solid-state ${ }^{31} \mathrm{P}$ magic-angle spinning (MAS) NMR spectroscopy of adsorbed TMPO and TBPO, in conjunction with elemental analysis.

\section{Experimental}

\subsection{Sample preparation}

The zeolite samples were prepared from a commercial $\mathrm{NaY}$-type zeolite with a $\mathrm{Si} / \mathrm{Al}$ ratio of 2.5 using an ion-exchange method. The NaY zeolite was converted to $\mathrm{NH}_{4} \mathrm{Y}$ with $\mathrm{NH}_{4} \mathrm{Cl}$; $\mathrm{NH}_{4} \mathrm{Y}$ was treated in a chloride solution $\left(\mathrm{RECl}_{3}, \mathrm{RE}=\mathrm{La}, \mathrm{Ce}\right)$ at $90{ }^{\circ} \mathrm{C}$ for $2 \mathrm{~h}$ to give the $\mathrm{NH}_{4} \mathrm{REY}$ zeolite. The RE content in the zeolite was varied by changing the concentration of the chloride solution. The $\mathrm{NH}_{4} \mathrm{REY}$ zeolite was calcined at $500{ }^{\circ} \mathrm{C}$ for 5 $\mathrm{h}$, thoroughly washed with demineralized water, dried overnight, and calcined at $400{ }^{\circ} \mathrm{C}$ for $2 \mathrm{~h}$. The zeolite samples obtained were denoted by REHY- $x$, where $x$ indicates the $\mathrm{RE}_{2} \mathrm{O}_{3}$ mass content (\%).

\subsection{Sample characterization}

All solid-state NMR experiments were carried out using a Bruker MSL-500P spectrometer at room temperature. ${ }^{31 P}$ MAS NMR spectra were acquired at a Larmor frequency of 202.46 MHz using a single-pulse sequence with a pulse width of $1.8 \mu \mathrm{s}$, a recycle delay of $10 \mathrm{~s}$, and a typical sample-spinning frequency of $12 \mathrm{kHz}$. A single-pulse sequence was also used for ${ }^{27} \mathrm{Al}$ MAS NMR experiments, with a sample-spinning rate of $12 \mathrm{kHz}$, pulse-width of $1.0 \mu \mathrm{s}$, and recycling delay of $500 \mathrm{~ms}$ at a resonance frequency of $130.32 \mathrm{MHz}$. Aqueous $85 \% \mathrm{H}_{3} \mathrm{PO}_{4}$ and $\mathrm{Al}\left(\mathrm{H}_{2} \mathrm{O}\right)_{6}{ }^{3+}$ solutions $(1 \mathrm{~mol} / \mathrm{L})$ were used as external references for the ${ }^{31} \mathrm{P}$ and ${ }^{27} \mathrm{Al}$ NMR chemical shifts, respectively.

Prior to the ${ }^{31} \mathrm{P}$ MAS NMR experiments, each sample was dehydrated at $350{ }^{\circ} \mathrm{C}$ for $24 \mathrm{~h}$ under vacuum $\left(133.32 \times 10^{-5}\right.$ $\mathrm{Pa}$ ). Details of the procedures for introducing the phosphine oxide (TMPO or TBPO) probe molecule into the sample can be found elsewhere [11]. In brief, a known amount of TMPO (100\%, Alfa) or TBPO (98\%, Acros) dissolved in anhydrous $\mathrm{CH}_{2} \mathrm{Cl}_{2}$ was added (using a gas-tight syringe) in a $\mathrm{N}_{2}$ glove box to a vessel containing a dehydrated sample; the loaded sample was agitated in an ultrasonic shaker for $30 \mathrm{~min}$ for thorough mixing, and then the $\mathrm{CH}_{2} \mathrm{Cl}_{2}$ solvent was removed by extraction (under liquid $\mathrm{N}_{2}$ ) and then evacuation for $12 \mathrm{~h}$. To ensure uni- form adsorption of the probe molecules on the sample, the sealed sample vessel was subjected to thermal treatment at $140{ }^{\circ} \mathrm{C}$ for $1 \mathrm{~h}$. Finally, the sample vessel was placed in the $\mathrm{N}_{2}$ glove box, where the sample was transferred into a $\mathrm{ZrO}_{2} \mathrm{MAS}$ rotor ( $4 \mathrm{~mm}$ o.d.), which was sealed with a gas-tight Kel-F cap.

For quantitative determination of the acid sites, each adsorbate-loaded sample was subjected to elemental analysis using ICP-MS (Jarrell-Ash, ICAP 9000). Typically, the adsorbate-loaded sample (ca. $0.1 \mathrm{~g}$ ) was dissolved in a mixture of HF, $\mathrm{HNO}_{3}$, and $\mathrm{HCl}(10 \mathrm{~mL})$, and the solution was added to a saturated boric acid solution $(60 \mathrm{~mL})$ at room temperature. The amounts of $\mathrm{P}, \mathrm{Al}$, and $\mathrm{Si}$ were then determined using the respective commercial standards.

Adsorbed pyridine Fourier transform infrared spectroscopy (Py-IR) was also used to determine the acidity. Prior to each Py-IR experiment (Thermo Nicolet NEXUS 750), a compressed sample (in the form of a self-supporting wafer, ca. $6 \mathrm{mg} / \mathrm{cm}^{2}$ ) was placed in the IR cell (with $\mathrm{ZnSe}$ windows) and evacuated at $450{ }^{\circ} \mathrm{C}$ for $2 \mathrm{~h}$, followed by saturation adsorption of pyridine at room temperature and subsequent removal of the physisorbed pyridine under vacuum. Pyridine desorption took place at 200 ${ }^{\circ} \mathrm{C}$. Each Py-IR spectrum was acquired by scanning from 4000 to $900 \mathrm{~cm}^{-1}$. The numbers of Brönsted (B) acid sites and Lewis (L) acid sites were determined from the IR absorption bands of pyridine at 1545 and $1450 \mathrm{~cm}^{-1}$, respectively [12].

The crystallinity of the zeolite samples was determined using a Philips X'Pert X-ray diffractometer with copper $K_{\alpha}$ radiation. Nitrogen physisorption measurements were performed at liquid-nitrogen temperature with a Micrometritics ASAP 2405N V1.01 apparatus. The surface area was determined by the BET method, and the micropore volum was determined from the intercept of the liner part of the $t$-plot.

\section{Results and discussion}

\subsection{Identification of ${ }^{31 P}$ NMR chemical shifts and REHY zeolite acid sites}

The structural features of the samples were determined using powder X-ray diffraction (XRD). The crystallinity, cell parameter $\alpha_{0}$, molar $\mathrm{Si} / \mathrm{Al}$ ratio, $\mathrm{BET}$ surface area, and pore volume were determined using XRD, ${ }^{29} \mathrm{Si}$ MAS NMR spectroscopy, and $\mathrm{N}_{2}$ adsorption/desorption measurements. The characteristics of these samples are listed in Table 1.

The 31P MAS NMR spectra of TMPO and TBPO adsorbed on REHY-8 are shown in Figure 1. The ${ }^{31 P}$ NMR spectra of the REHY zeolite samples with various RE contents were similar, so REHY-8 was taken as an example. The dashed curves represent

Table 1

Physical properties of the zeolite samples.

\begin{tabular}{lcccccc}
\hline Sample & $\begin{array}{c}\mathrm{RE}_{2} \mathrm{O}_{3} \\
(\%)\end{array}$ & $\begin{array}{c}\alpha_{0} \\
(\mathrm{~nm})\end{array}$ & $\begin{array}{c}\text { Crystallinity } \\
(\%)\end{array}$ & $\begin{array}{c}\mathrm{Si} / \mathrm{Al} \\
\text { ratio }\end{array}$ & $\begin{array}{c}S_{\text {Micro }} \\
\left(\mathrm{m}^{2} / \mathrm{g}\right)\end{array}$ & $\begin{array}{c}V_{\text {Micro }} \\
(\mathrm{mL} / \mathrm{g})\end{array}$ \\
\hline HY & - & 2.466 & 82.7 & 3.7 & 536 & 0.247 \\
REHY-4 & 3.1 & 2.458 & 66.0 & 4.4 & 586 & 0.269 \\
REHY-8 & 7.6 & 2.461 & 59.7 & 3.8 & 591 & 0.272 \\
REHY-14 & 13.7 & 2.466 & 51.3 & 3.4 & 535 & 0.247 \\
REHY-28 & 26.2 & 2.482 & 49.2 & 2.4 & 512 & 0.236 \\
\hline
\end{tabular}


the results of spectral simulation by Gaussian deconvolution. A Win-NMR software program (Bruker Biospin) enabled curve fitting through appropriate choice of 31P NMR peaks, based on the observed resonance line-shape. A simulated spectrum nearly identical to the observed spectrum was considered to be a good fit. The simulation results for REHY-8/TMPO had nine resonance peaks at $\delta=78,70,65,62,58,55,53,49$, and 41 . The two peaks at $\delta<50$ can be unambiguously assigned to physisorbed TMPO and are therefore irrelevant in terms of the acidic properties of the sample being examined [13]. The assignments of the peaks at higher chemical shifts remains controversial; for example, Zhao et al. [14] concluded that the ${ }^{31} \mathrm{P}$ resonances at $\delta=60-65$ were associated with TMPO adsorbed on L acid sites, whereas Mueller's group [15] suggested that the peak at $\delta=63$ arose from interactions between TMPO and B acid sites.

Additional experiments were performed to confirm the resonance assignments. The TMPO-loaded sample was exposed to humidity, and the specific chemical shifts and corresponding integrated areas in each spectrum are given in Figure 2(a) and Table 2. It is known that $\mathrm{L}$ acid sites can react easily with water to form B acid sites [16]. However, the strong hydrogen bonds between the adsorbed TMPO molecules and B acid sites are unlikely to be dissociated in the presence of water. Consequently, only the ${ }^{31} \mathrm{P}$ resonances associated with $\mathrm{L}$ acid sites will decrease when the sample is hydrated. The data in Table 2
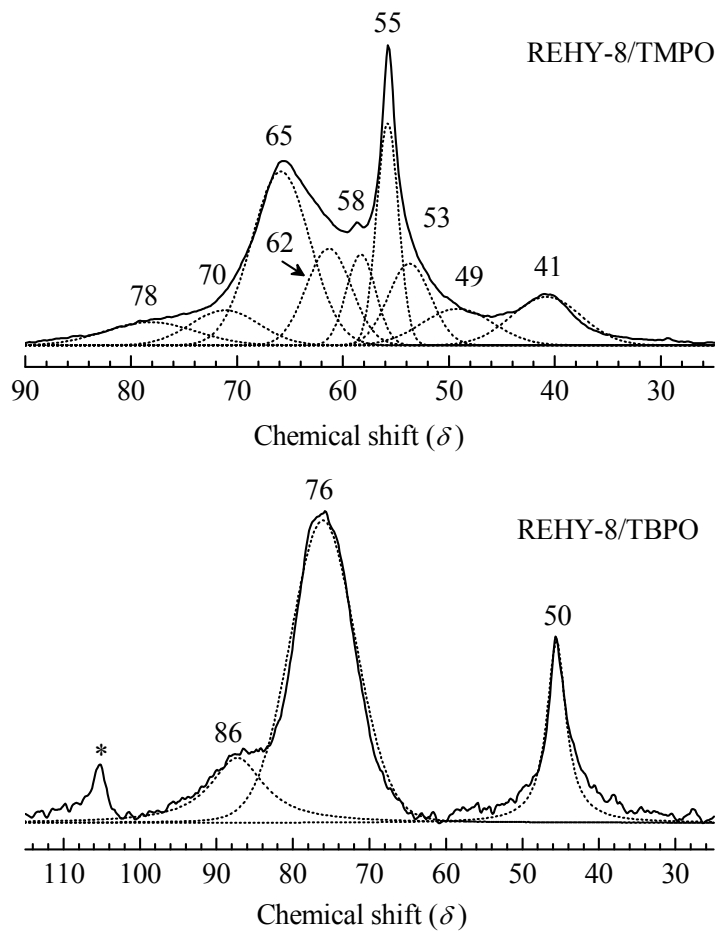

Fig. 1. ${ }^{31 P}$ MAS NMR spectra of TMPO and TBPO adsorbed on the REHY-8 sample. The dashed curves indicate the results of spectroscopic analyses by Gaussian deconvolution.
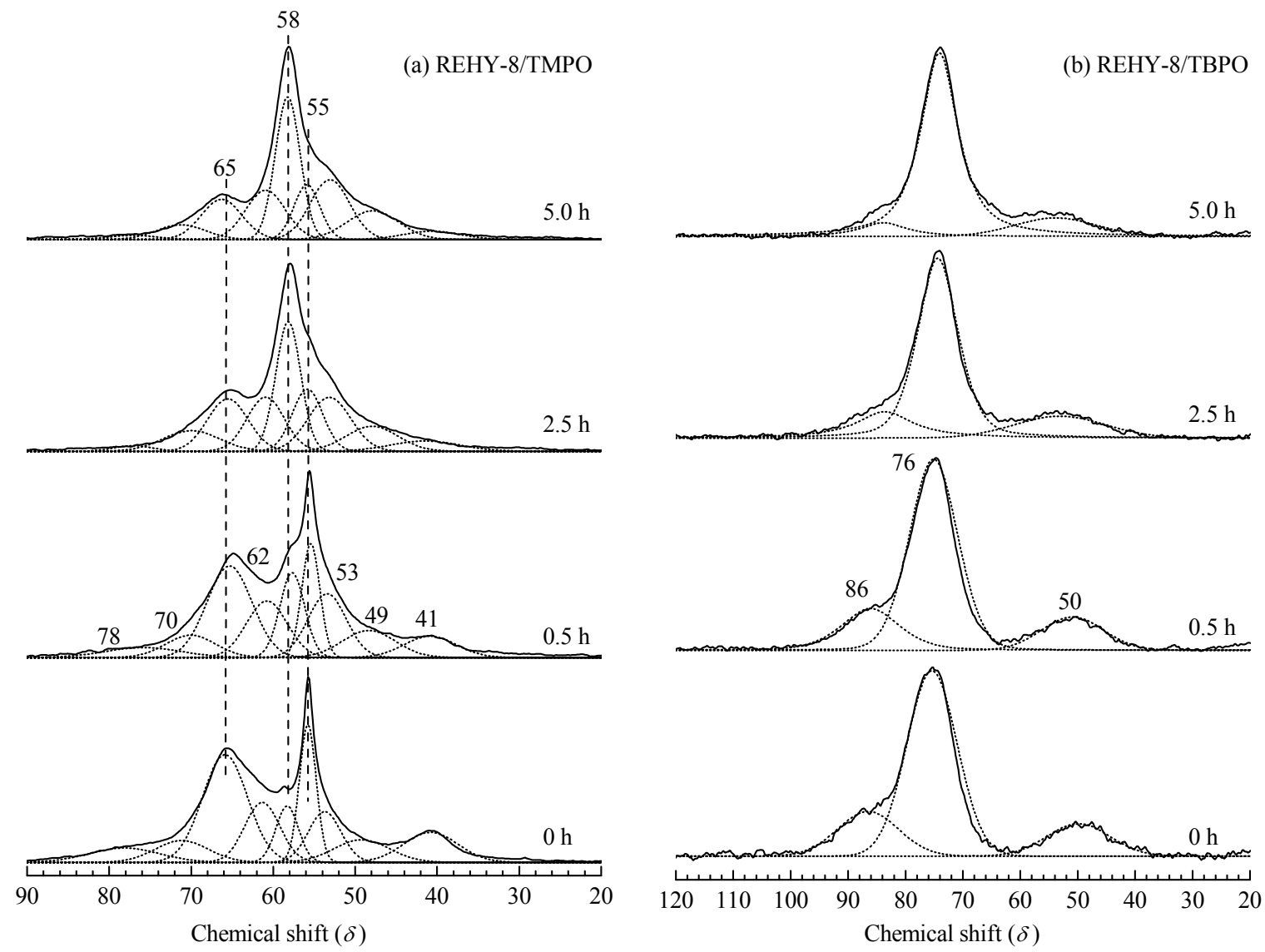

Fig. 2. ${ }^{31}$ P MAS NMR spectra of TMPO (a) and TBPO (b) adsorbed on REHY-8 sample before $(0 \mathrm{~h})$ and after partial hydration by exposure of adsorbed samples to humidity for $0.5,2.5$, and $5.0 \mathrm{~h}$. 
Table 2

${ }^{31}$ P NMR chemical shifts and relative peak areas (\%) for REHY-8/TMPO samples exposed to humidity for various times.

\begin{tabular}{lccccccc}
\hline Time & \multicolumn{7}{c}{ Relative peak area (\%) } \\
\cline { 2 - 8 }$(\mathrm{h})$ & $\delta=78$ & $\delta=70$ & $\delta=65$ & $\delta=62$ & $\delta=58$ & $\delta=55$ & $\delta=53$ \\
\hline 0 & 2.8 & 7.2 & 32.1 & 11.5 & 10.0 & 28.8 & 7.6 \\
0.5 & 2.2 & 7.5 & 30.8 & 13.3 & 15.0 & 20.8 & 10.4 \\
2.5 & 1.7 & 8.1 & 26.4 & 13.6 & 22.7 & 14.6 & 12.9 \\
5.0 & 1.3 & 6.0 & 23.8 & 14.5 & 29.3 & 10.0 & 15.1 \\
\hline
\end{tabular}

Table 3

${ }^{31} \mathrm{P}$ NMR chemical shifts and relative peak areas (\%) for REHY-8/TBPO samples exposed to humidity for various times.

\begin{tabular}{lll}
\hline \multirow{2}{*}{ Time (h) } & \multicolumn{2}{c}{ Relative peak area (\%) } \\
\cline { 2 - 3 } & $\delta=86$ & $\delta=76$ \\
\hline 0 & 24.15 & 75.85 \\
0.5 & 20.22 & 79.78 \\
2.5 & 15.96 & 84.04 \\
5.0 & 11.55 & 88.45 \\
\hline
\end{tabular}

and Figure 2 show that the peaks at $\delta=78$ and 55 can be ascribed to interactions of TMPO with L acid sites, and the peaks at $\delta=70,65,62,58$, and 53 can be ascribed to interactions of TMPO with B acid sites.

In the case of adsorbed TBPO, only three peaks were observed for REHY-8/TBPO at $\delta=86,76$, and 50 (Figure 1). The resonance with the lowest chemical shift $(\delta=50)$ can be assigned to physisorbed TBPO. On exposure of the adsorbate sample to humidity, the peak intensity at $\delta=86$ decreased, and that of the peak at $\delta=76$ increased, with increasing water content (see Figure 2(b) and Table 3). The peaks at $\delta=86$ and 76 were therefore associated with $\mathrm{L}$ acid sites and B acid sites, respectively.

31P NMR results obtained for TMPO adsorbed on REHY zeolite provide information on both internal and external acid sites, whereas TBPO systems exclusively provided information on acid sites located on the external surface [11]. Before performing further experiments, it was therefore necessary to clarify the distributions and locations of the acid sites. It was important to combine the results obtained separately using the homologous probe molecules, TMPO and TBPO, to identify the internal and external acid sites.

An earlier study [16] showed that the respective ${ }^{31} \mathrm{P}$ resonances observed for TMPO and TBPO adsorbed on acid sites with the same acid strength can be correlated based on the differences $(\Delta \delta \pm 3)$ between the observed chemical shifts and those of their crystalline bulks, namely $\delta=39$ for TMPO and $\delta=$ 47 for TBPO. For example, for REHY-8, up to seven peaks can be resolved from the ${ }^{31} \mathrm{P}$ NMR of adsorbed TMPO, at $\delta=78,70$, $65,62,58,55$, and 53 (in order of decreasing acid strength), whereas only two resonances can be identified in the case of adsorbed TBPO (i.e., $\delta=86$ and 76). The resonances at $\delta=86$ and 76, with respective $\Delta \delta$ values of 39 and 29 , can therefore be correlated with the resonances at $\delta=78$ and 70, obtained from TMPO, which were found to have similar respective $\Delta \delta$ values. It can therefore be concluded that the peaks at $\delta=78$ and 70 observed for the REHY-8/TMPO system represented internal and external acid sites. Furthermore, for the same system
(REHY-8/TMPO), the other peaks at $\delta=65,62,58,55$, and 53, which corresponded to respective $\Delta \delta$ values of $26,23,19,16$, and 14 , were not visible in the spectrum obtained from REHY-8/TBPO. These peaks can therefore be attributed to TMPO adsorbed on acid sites located in the internal channels of the REHY-8 sample.

\subsection{Quantitative determination of acid sites on REHY zeolite}

Figure 3 shows the ${ }^{31 P}$ MAS NMR spectra of TMPO and TBPO adsorbed on REHY zeolite. It was found that no new resonance peaks emerged as the RE content of the $\mathrm{Y}$ zeolite increased. However, the relative concentrations of acid sites with the same acid strength clearly changed.

To clarify the effects of RE cations on Y zeolite acidity further, additional quantitative information on the acid sites is needed; this can be obtained from ICP-MS analysis for $\mathrm{Si}, \mathrm{Al}$, and $\mathrm{P}$; the results are listed in Tables 4 and 5 . The amounts (mmol/g) of B acid and $\mathrm{L}$ acid sites can then be derived using the renormalized (i.e., after excluding contributions from physisorbed TMPO or TBPO) relative concentrations obtained from spectral simulation by Gaussian deconvolution, based on the assumption that each TMPO or TBPO molecule can only be adsorbed on either one B or L acid site [14], i.e., TMPO or TBPO was adsorbed on the acid sites on a 1:1 basis.

The conclusions drawn from a comparison of the results shown in Table 4 are summarized below and are clearly shown in Table 6.

In terms of the overall (internal and external) acidity, the total number of acid sites on REHY zeolite decreased with increasing $\mathrm{RE}_{2} \mathrm{O}_{3}$ content; for example, the number of acid sites on REHY-4, REHY-8, REHY-14, and REHY-28 were 2.09, 2.04, 1.93 , and $0.99 \mathrm{mmol} / \mathrm{g}$, respectively. In particular, the number of $\mathrm{L}$ acid sites decreased significantly when the $\mathrm{RE}_{2} \mathrm{O}_{3}$ content was increased from $4 \%$ to $28 \%$, but a large decrease in the number of $\mathrm{B}$ acid sites was only observed when the $\mathrm{RE}_{2} \mathrm{O}_{3}$ content was very high (28\%). The ratio of $\mathrm{B}$ to $\mathrm{L}$ acid sites therefore increased on incorporation of RE into $\mathrm{Y}$ zeolite.

In terms of acid strength, when the $\mathrm{RE}_{2} \mathrm{O}_{3}$ content was $14 \%$ or less, the incorporation of RE into the $\mathrm{Y}$ zeolite resulted in a clear increase in the number of medium strength $(\delta=62$ and 58) B acid sites, and significant decreases in the numbers of weak ( $\delta=55) \mathrm{L}$ acid sites and strong $(\delta=65) \mathrm{B}$ acid sites. When the content of $\mathrm{RE}_{2} \mathrm{O}_{3}$ was very high $(28 \%)$, the number of $\mathrm{B}$ acid sites decreased greatly.

In terms of the distribution of acid sites, the acid sites (B and L) were mainly located inside the Y zeolite cages, i.e., internal acid sites, and these consisted of B acid sites of various strength and weak L acid sites; only $5 \%-10 \%$ of the total acidity was contributed by acid sites located on the external surfaces of the Y zeolite.

To confirm the results from ${ }^{31} \mathrm{P}$ MAS NMR, Py-IR was used to characterize the acidic properties of various samples. Py-IR is a useful technique and is commonly used for the identification of $B$ acid and $L$ acid sites. The adsorbed pyridine probe molecules couple with L acid and/or B acid sites through the nitrogen lone-pair electrons and can therefore be monitored using their 
(a) TMPO
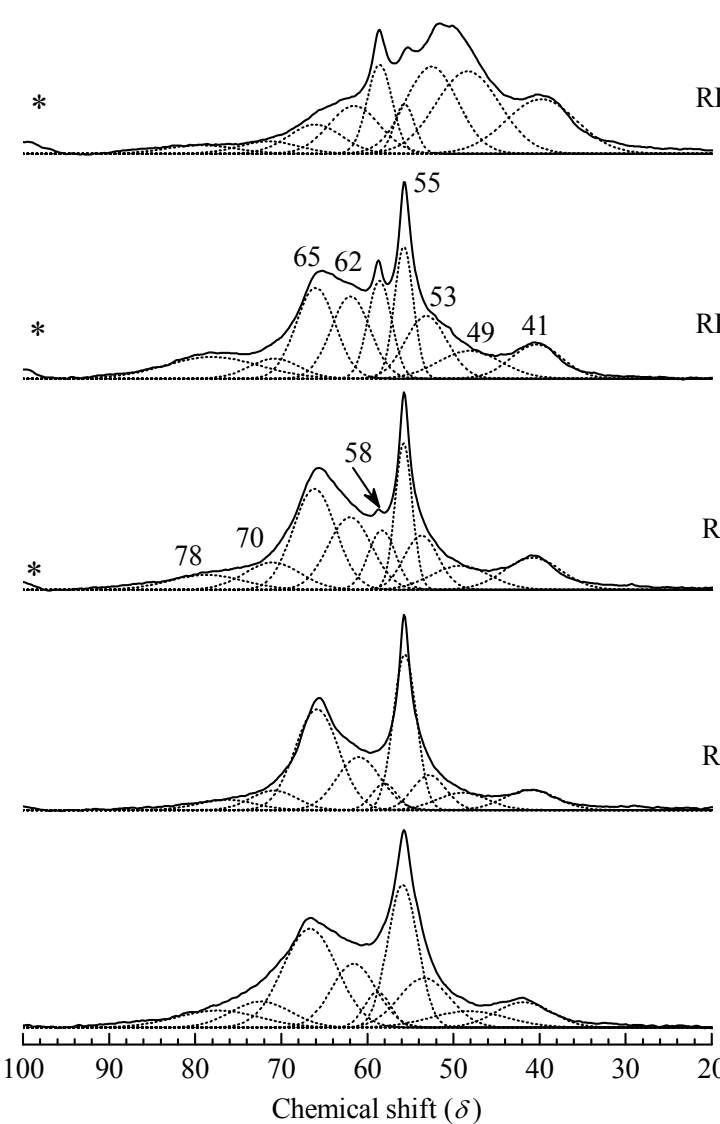

Fig. 3. ${ }^{31 P}$ MAS NMR spectra of REHY zeolite with TMPO (a) and TBPO (b). The asterisks denote spin side-bands.

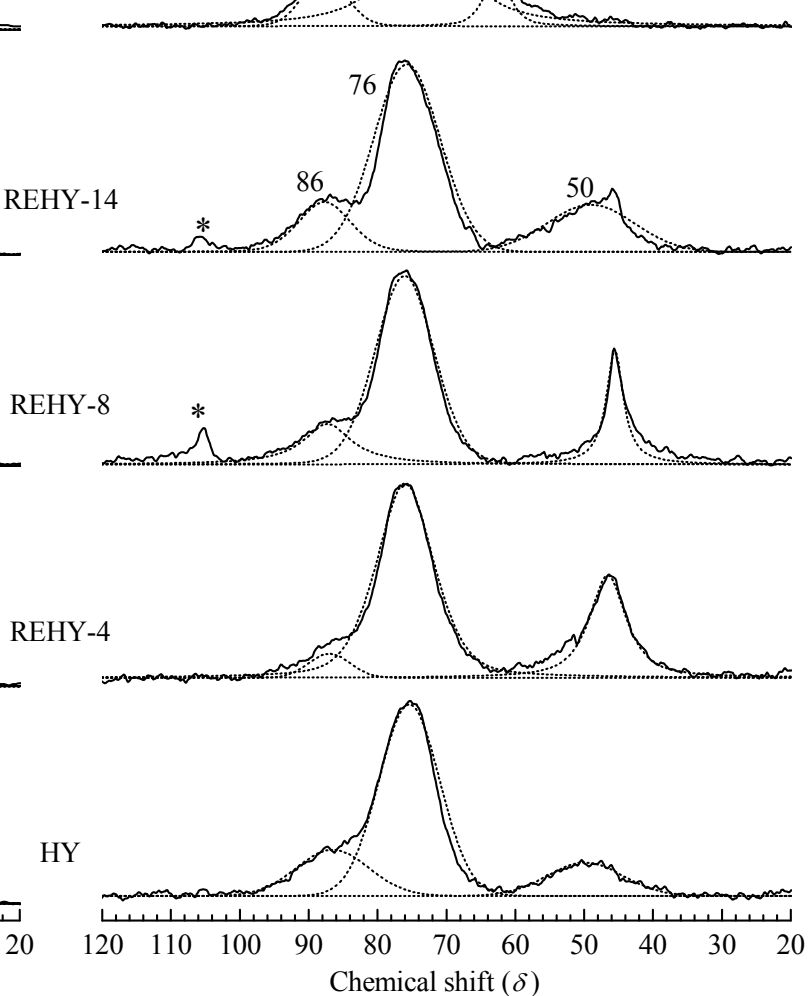

(b) TBPO ring vibrations. The numbers and distributions of acid sites (B and $\mathrm{L}$ ) determined from IR spectra after the adsorption and desorption of pyridine at $200{ }^{\circ} \mathrm{C}$ are shown in Figure 4. In general, the total number of acid sites, particularly $\mathrm{L}$ acid sites, decreased with increasing $\mathrm{RE}_{2} \mathrm{O}_{3}$ content. The number of $\mathrm{B}$ acid sites did not change significantly when the $\mathrm{RE}_{2} \mathrm{O}_{3}$ content increased from $4 \%$ to $14 \%$, but decreased greatly when the $\mathrm{RE}_{2} \mathrm{O}_{3}$ content was about $28 \%$. These results were mostly in agreement with those obtained using ${ }^{31}$ P MAS NMR. However, acidity characterization using Py-IR was limited because it cannot provide information on the distributions of sites with different acid strengths and the locations of acid sites. In contrast, the combination of 31 P MAS NMR and ICP-MS used in this study enabled detailed qualitative and quantitative information on acid sites to be obtained simultaneously, and also enabled monitoring of changes in the strengths and concentrations of acid sites on the samples.

\subsection{Effects of RE cations on Y zeolite acidity}

The XRD and ${ }^{29}$ Si MAS NMR results show that the unit cell size $\left(\alpha_{0}\right)$ increased with increasing RE content, as did the number of framework $\mathrm{Al}$ atoms; this indicates that the introduction of RE cations prevented shrinkage of the unit cell and formation of extra-framework Al. Previous theoretical research [17] showed, using density functional theory, that the RE spe-

Table 4

${ }^{31}$ P MAS NMR chemical shift assignments and distributions of acid sites of samples loaded with TMPO probe molecules.

\begin{tabular}{|c|c|c|c|c|c|c|c|c|c|c|c|}
\hline \multirow[t]{2}{*}{ Sample } & \multicolumn{7}{|c|}{ Relative concentration of acid sites ${ }^{a}(\%)$} & \multicolumn{3}{|c|}{$\begin{array}{l}\text { Acid amount } \\
\text { (mmol/g) }\end{array}$} & \multirow[t]{2}{*}{$\mathrm{B} / \mathrm{L}$} \\
\hline & $\delta(\Delta \delta)^{\mathrm{b}}=78(39)$ & $70(31)$ & 6) & 3) & 9) & $55(16)$ & $53(14)$ & B & $\mathrm{L}$ & $B+L$ & \\
\hline Y & $2.4(0.02,0.03)$ & 500400 & $7.5(0.80,-)$ & $2.6(0.27,-)$ & $6.4(0.14,-)$ & $5.1(0.53,-)$ & $21,-)$ & 1.54 & 0.58 & 2.12 & \\
\hline REHY-4 & $2.8(0$ & $7.6(0.06$ & $34.2(0.71,-)$ & $10.4(0.22,-)$ & $4,-)$ & $32.0(0.67,-)$ & 6.4 & 1.36 & 0.73 & 2.09 & \\
\hline REHY-8 & $2.8(0.03,0.03)$ & $7.2(0.04,0.10)$ & $32.1(0.65,-)$ & $11.5(0.23,-)$ & $10.0(0.20,-)$ & $28.8(0.59,-)$ & $7.6(0.16,-)$ & 1.40 & 0.64 & 2.04 & 2.1 \\
\hline EHY-14 & $3.2(0.03$, & $.0(0.04,0$ & $27.3(0.53,-)$ & $13.2(0.25,-)$ & $15.7(0.30,-)$ & $22.9(0.44,-)$ & $10.7(0.21,-)$ & 1.43 & 0.50 & 1.93 & 2.8 \\
\hline 2EHY-28 & $3.4(0.01,0.02)$ & $5.6(0.02,0.04)$ & $16.9(0.17,-)$ & $18.5(0.18,-)$ & $18.0(0.18,-)$ & $16.7(0.17,-)$ & $20.9(0.21,-)$ & 0.79 & 0.20 & 0.99 & 3.9 \\
\hline
\end{tabular}

a Data in parentheses (internal, external) give the number of internal and external acid sites $( \pm 0.002 \mathrm{mmol} / \mathrm{g}$ ).

${ }^{\mathrm{b}} \delta$ is the chemical shifts of characteristic peaks, and the numbers in parentheses $(\Delta \delta)$ refer to the corresponding chemical shift differences with respect to crystalline TMPO $(\delta=39)$. 
Table 5

31P MAS NMR chemical shift assignments and distributions of acid sites of samples loaded with TBPO probe molecules.

\begin{tabular}{|c|c|c|c|}
\hline \multirow{2}{*}{ Sample } & \multicolumn{2}{|c|}{ Relative concentration of acid sites (\%) } & \multirow{2}{*}{$\begin{array}{l}\text { Acid amount } \\
(\mathrm{mmol} / \mathrm{g})\end{array}$} \\
\hline & $\delta(\Delta \delta)^{\mathrm{a}}=86(39)$ & $76(29)$ & \\
\hline HY & 21.0 & 79.0 & 0.12 \\
\hline REHY-4 & 19.9 & 80.1 & 0.13 \\
\hline REHY-8 & 24.1 & 75.9 & 0.14 \\
\hline REHY-14 & 25.6 & 74.4 & 0.13 \\
\hline REHY-28 & 28.5 & 71.5 & 0.06 \\
\hline
\end{tabular}

a $\delta$ is the chemical shifts of characteristic peaks, and the numbers in parentheses $(\Delta \delta)$ refer to the corresponding chemical shift differences with respect to crystalline TBPO $(\delta=47)$.

Table 6

Acid site distributions on REHY zeolites.

\begin{tabular}{lccccc}
\hline & \multicolumn{5}{c}{ Acid amount (mmol/g) } \\
\cline { 2 - 6 } Sample & Total & $\begin{array}{c}\text { L } \\
(\delta=78,55)\end{array}$ & $\begin{array}{c}\text { Strong B } \\
(\delta=65)\end{array}$ & $\begin{array}{c}\text { Medium B } \\
(\delta=62,58)\end{array}$ & $\begin{array}{c}\text { Other B } \\
(\delta=70,53)\end{array}$ \\
\hline REHY-4 & 2.09 & 0.73 & 0.71 & 0.36 & 0.29 \\
REHY-8 & 2.04 & 0.64 & 0.65 & 0.44 & 0.30 \\
REHY-14 & 1.93 & 0.50 & 0.53 & 0.56 & 0.34 \\
REHY-28 & 0.99 & 0.20 & 0.17 & 0.36 & 0.26 \\
\hline
\end{tabular}

cies and Y zeolite clusters interact strongly, and this strengthens the interactions between framework $\mathrm{Al}$ and neighboring $\mathrm{O}$ atoms, inhibits framework dealumination and formation of extra-framework $\mathrm{Al}$, and significantly enhances the $\mathrm{Y}$ zeolite stability.

The influences of framework and extra-framework Al species and RE cations on the Y zeolite acidity can be explained by the following model (Figure 5). (1) When the REHY zeolite is prepared from $\mathrm{NaY}$ using an ion-exchange method, the polarization effect of $\mathrm{RE}^{3+}$ on water results in the formation of $\mathrm{RE}(\mathrm{OH})^{2+}[18]$. Under heat treatment conditions, $\mathrm{RE}(\mathrm{OH})^{2+}$ can move from the supercage to the sodalite cage I' sites of the $Y$ zeolite, and then bond strongly with 03 and 02 , leading to enhanced stability of the Y zeolite [17]. (2) With regard to B acid strength, it is accepted that heat treatment can cause the release of $\mathrm{Al}$ atoms from the $\mathrm{Y}$ zeolite framework, leading to the formation of extra-framework $\mathrm{Al}$ species. It has been shown

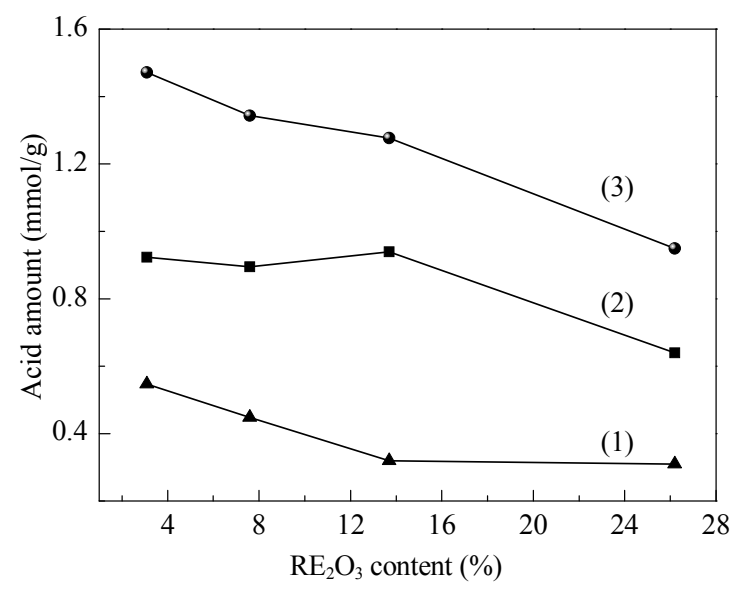

Fig. 4. Py-IR data for $\mathrm{REHY}$ samples with various $\mathrm{RE}_{2} \mathrm{O}_{3}$ contents. (1) $\mathrm{L}$ acid; (2) B acid; (3) Total acid. The number of B acid and L acid sites was determined based on the pyridine absorption bands at 1545 and $1450 \mathrm{~cm}^{-1}$, respectively.

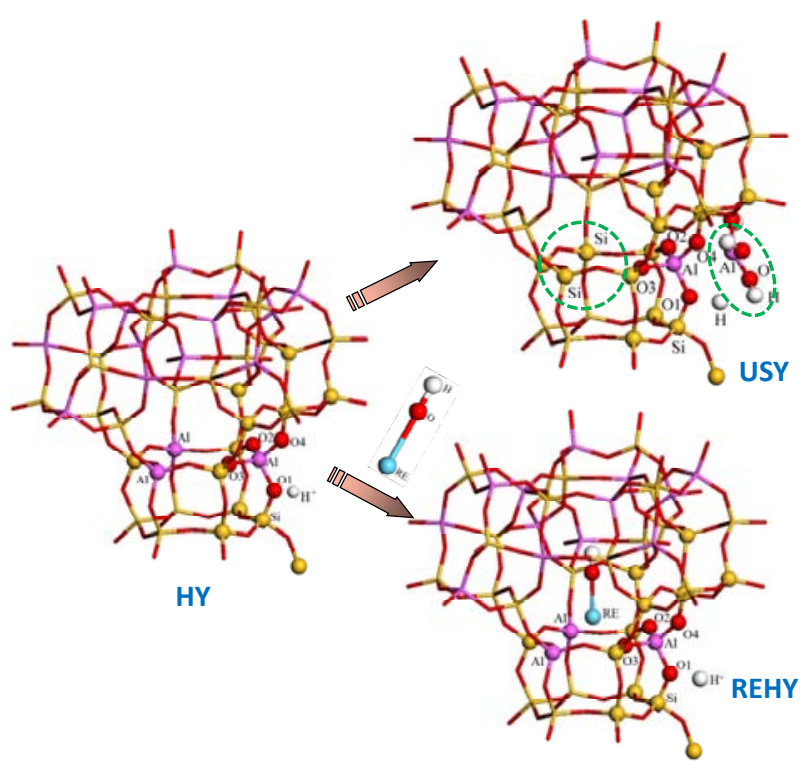

Fig. 5. Mechanism model for effects of RE on Y zeolite acidity.

that a decrease in the framework $\mathrm{Al}$ content [19] and the presence of extra-framework $\mathrm{Al}$ species [20] both lead to formation of strong B acid sites on dealuminated HY (USY) zeolite. The enhanced stability of the REHY zeolite suppresses the release of framework $\mathrm{Al}$ and the formation of extra-framework $\mathrm{Al}$, leading to weaker B acid sites on REHY zeolite than on USY zeolite. $\mathrm{RE}(\mathrm{OH})^{2+}$ species located in the sodalite cage I' sites of Y zeolite result in stronger B acid sites on REHY zeolite than on HY zeolite. The order of the B acid site strength is therefore USY > REHY> HY. (3) In terms of the number of B acid sites, the HY zeolite, which is prepared from $\mathrm{NaY}$ by $\mathrm{NH}_{4}{ }^{+}$exchange with $\mathrm{Na}^{+}$ and $\mathrm{NH}_{3}$ release, has the most $\mathrm{B}$ acid sites. The USY zeolite, which is obtained by dealumination of HY under heat treatment conditions, has the fewest B acid sites. REHY zeolites are obtained from $\mathrm{NaY}$ by $\mathrm{RE}(\mathrm{OH})^{2+}$ exchange with two $\mathrm{Na}^{+}$ions in the sodalite cage, followed by $\mathrm{NH}_{4}{ }^{+}$exchange with the remaining $\mathrm{Na}^{+} ; \mathrm{H}^{+}$is produced by hydrolysis exchange with $\mathrm{Na}^{+}$in the supercage, so REHY zeolites have fewer B acid sites than HY zeolite [21]. The higher stability of REHY zeolite compared with HY zeolite suppresses zeolite dealumination, so REHY zeolite has larger numbers of B acid sites than USY zeolite. The order of the numbers of B acid sites is therefore HY > REHY > USY.

The number of medium strength $\mathrm{B}$ acid sites (with 31P NMR/TMPO at $\delta=62$ and 58) increases significantly with increasing RE content, whereas the numbers of strong $\mathrm{B}$ acid sites (with ${ }^{31} \mathrm{P}$ NMR/TMPO at $\delta=65$ ) and weak L acid sites both decrease.

\section{Conclusions}

The acidic properties (i.e., types, locations, concentrations, and strengths of acid sites) of REHY zeolite were characterized using solid-state ${ }^{31} \mathrm{P}$ MAS NMR of adsorbed phosphine oxide probe molecules (TMPO and TBPO). In particular, the distributions and concentrations of internal and external acid sites were differentiated using a combination of elemental analysis 


\section{Graphical Abstract}

Chin. J. Catal., 2014, 35: 1318-1328 doi: 10.1016/S1872-2067(14)60149-2

\section{Acidity characterization of rare-earth-exchanged Y zeolite using ${ }^{31 P}$ MAS NMR}

Shanqing $\mathrm{Yu}^{*}$, Huiping Tian

Research Institute of Petroleum Processing, SINOPEC

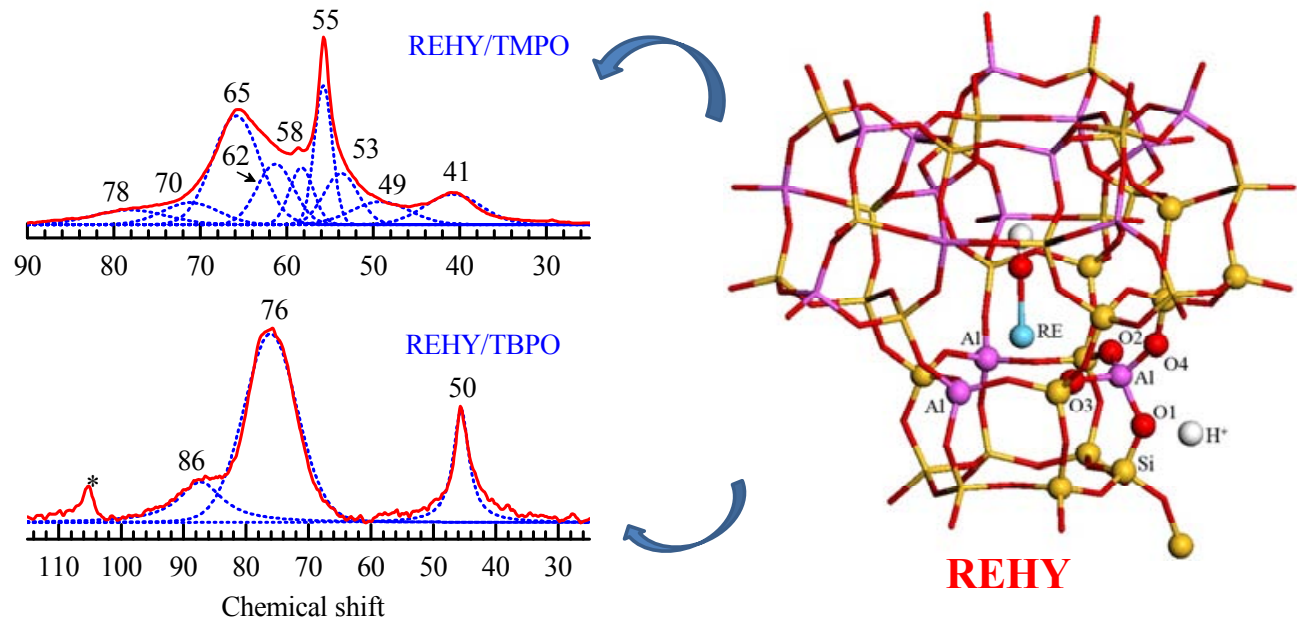

The detailed acidic properties (i.e., types, locations, concentrations, and strengths of acid sites) of rare-earth-exchanged Y zeolite (REHY) were characterized using solid-state 31P MAS NMR of adsorbed phosphine oxide probe molecules trimethylphosphine oxide (TMPO) and tributylphosphine oxide (TBPO).

and 31P MAS NMR of adsorbed phosphorus probe molecules. Five $B$ acid sites and two $L$ acid sites of various acid strengths were identified for $\mathrm{Y}$ zeolite. Among these, four of the five B acid sites, with different acid strengths, and one of the $\mathrm{L}$ acid sites, which was weak, were found to be internal sites, and one $B$ acid site and one $L$ acid site were associated with external sites. The concentration of internal $\mathrm{B}$ acid sites of medium strength increased significantly with increasing $\mathrm{RE}_{2} \mathrm{O}_{3}$ content, and that of $\mathrm{L}$ acid sites decreased accordingly, when the $\mathrm{RE}_{2} \mathrm{O}_{3}$ content was $14 \%$ or less. The total number of acid sites on the REHY zeolite, especially the number of $\mathrm{L}$ acid sites, decreased with increasing $\mathrm{RE}_{2} \mathrm{O}_{3}$ content.

\section{Acknowledgments}

This work was mainly done at Institute of Atomic and Molecular Sciences, Academia Sinica, Taipei. We sincerely thank Prof. Shangbin Liu for helpful discussion.

\section{References}

[1] Noda T, Suzuki K, Katada N, Niwa M. J Catal, 2008, 259: 203

[2] Pang X M, Zhang L, Sun S H, Liu T, Gao X H. Catal Today, 2007, 125: 173

[3] Shen B J, Qin Z X, Gao X H, Lin F, Zhou S G, Shen W, Wang B J, Zhao H J, Liu H H. Chin J Catal (申宝剑, 覃正兴, 高雄厚, 林枫, 周淑歌, 沈文, 王宝杰, 赵红娟, 刘宏海. 催化学报), 2012, 33: 152

[4] Garcia P, Lima E, Aguilar J, Lara V. Catal Lett, 2009, 128: 385
[5] Richardson J T. J Catal, 1967, 9: 182

[6] Ward J W.J Catal, 1970, 17: 355

[7] Corma A, Fornes V, Melo F V, Herrero J. Zeolites, 1987, 7: 559

[8] Marcilla A, Gomez-Siurana A, Berenguer D. Appl Catal A, 2006, 301: 222

[9] Hunger M. Catal Rev-Sci Eng, 1997, 39: 345

[10] Rakiewicz E F, Peters A W, Wormsbecher R F, Sutovich K J, Mueller K T. J Phys Chem B, 1998, 102: 2890

[11] Chen W H, Tsai T C, Jong S J, Zhao Q Tsai C T, Wang I, Lee H K, Liu S B. J Mol Catal A, 2002, 181: 41

[12] Xu B, Bordiga S, Prins R, Van Bokhoven J A. Appl Catal A, 2007, 333: 245

[13] Zheng A M, Zhang H L, Lu X, Liu S B, Deng F. J Phys Chem B, 2008, 112: 4496

[14] Zhao Q, Chen W H, Huang S J, Liu S B. Stud Surf Sci Catal, 2003, 145: 205

[15] Karra M D, Sutovich K J, Mueller K T. J Am Chem Soc, 2002, 124: 902

[16] Zhao Q, Chen W H, Huang S J, Wu Y C, Lee H K, Liu S B.J Phys Chem $B, 2002,106: 4462$

[17] Yu S Q Tian H P, Dai Z Y, Long J. Chin J Catal (于善青, 田辉平, 代 振宇, 龙军. 催化学报), 2010, 31: 1263

[18] Olson D H, Kokotailo G T, Chamell J F. J Colloid Interf Sci, 1968, 28: 305

[19] Datka J, Gil B. J Catal, 1994, 145: 372

[20] Li S H, Huang S J, Shen W L, Zhang H L, Fang H J, Zheng A M, Liu S B, Deng F. J Phys Chem C, 2008, 112: 14486

[21] Yu S Q, Dai Z Y, Tian H P, Zhu Y X, Long J. Acta Petrol Sini (Petrol Process Sect) (于善青, 代振宇, 田辉平, 朱玉霞, 龙军. 石油学报 (石油加工)), 2011, 27: 839 


\title{
${ }^{31}$ P MAS NMR固体核磁共振研究稀土改性Y分子篮的酸性
}

\author{
于善青"，田辉平 \\ 中国石油化工股份有限公司石油化工科学研究院，北京100083
}

\begin{abstract}
摘要: 以三甲基磷氧(TMPO)和三丁基磷氧(TBPO)为探针分子, 用 ${ }^{31} \mathrm{P}$ 魔角旋转核磁共振 $\left({ }^{31} \mathrm{P}\right.$ MAS NMR)法对稀土改性Y型分子笁 的酸性进行了定性和定量分析. 结果表明, 以 TMPO为探针分子的 ${ }^{31} \mathrm{P}$ MAS NMR 谱分别在 $\delta=78,70,65,62,58,55$ 和 53 处存在与 酸中心相关的吸收峰, 其中 $\delta=78$ 和 70 处吸收峰与分子篮内部和外部酸性有关, $\delta=65,62,58$ 和 53 处吸收峰归属于TMPO在分子篮 内部Brönsted酸中心上的贡献, $\delta=55$ 处吸收峰归属于TMPO在分子篮内部Lewis酸中心上的贡献. 随着稀土含量的增加, 中等强度 Brönsted酸中心 $(\delta=62$ 和58)数量显著增加, 而强Brönsted酸中心 $(\delta=65)$ 和较弱Lewis酸中心 $(\delta=55)$ 数量显著降低. 结合分子篮骨 架铝和非骨架铝对分子篎酸性的影响进一步探讨了稀土改型Y分子篮的酸性.
\end{abstract}

关键词: Y型分子篮; 稀土; 酸性; ${ }^{31} \mathrm{P}$ 核磁共振

收稿日期: 2014-03-30. 接受日期：2014-05-13. 出版日期: 2014-08-20.

*通讯联系人. 电话: (010)82368972; 传真: (010)62311290; 电子信箱: yusq.ripp@sinopec.com

基金来源：国家重点基础研究发展计划(973 计划, 2003CB615804); 国家自然科学基金(20673054); 国家科技支撑计划 (2012BAE05B00).

本文的英文电子版由Elsevier出版社在ScienceDirect上出版(http://www.sciencedirect.com/science/journal/18722067).

\section{1. 前言}

稀土改性Y型分子篮作为催化裂化催化剂的活性组 分具有较高的活性和稳定性 ${ }^{[1-3]}$. 普遍认为, 稀土 $(\mathrm{La}$, $\mathrm{Ce}, \mathrm{Nd}, \mathrm{Sm}, \mathrm{Pr})$ 离子可通过表面修饰进入分子篎晶体内 部, 增强了分子篮骨架结构的稳定性 ${ }^{[3,4]}$. 稀土离子的另 一个重要作用是调变分子篮酸性, Richardson ${ }^{[5]}$ 阐述了稀 土离子交换 $\mathrm{Y}$ 分子篎的高稳定性, 认为稀土离子的极化 作用影响了Brönsted (B) $\mathrm{OH}$ 的强度. Ward ${ }^{[6]}$ 认为稀土离 子的高电价使水分子极化, 释放出氢质子, 从而提高了 分子篎的酸性. 因此, 详细研究稀土改型Y分子篎的酸 性(种类、数量、强度以及酸中心分布等)对于提高催化 剂性能和指导合成新型催化剂具有重要意义.

虽然关于稀土改性Y型分子篮的酸性已有大量的研 究, 但这些研究大多采用传统的酸性表征方法 ${ }^{[7-9]}$, 如程 序升温脱附(TPD)、红外光谱(IR) 以及 ${ }^{1} \mathrm{H}$ 核磁共振 $\left({ }^{1} \mathrm{H}\right.$ NMR). 而这些传统的酸性表征方法都无法给出酸性的 详细信息(如酸种类、酸数量、酸强度和不同强度酸中 心的分布等).

近年来, 固体核磁共振技术在酸性表征方面得到应 用 ${ }^{[10]}$, 结合探针分子的 ${ }^{31} \mathrm{P}$ 魔角旋转共振 $\left({ }^{31} \mathrm{P}\right.$ MAS NMR) 技术能够分析固体酸催化剂的酸类型、酸强度、酸量和 酸位分布, 常用的探针分子有三甲基磷氧(TMPO)和三 丁基磷氧化合物 (TBPO). TMPO的分子直径约为 0.55 $\mathrm{nm}$, 能进入分子篮内部, 因此可探测分子篮内外表面的 酸性; TBPO的分子直径约为 $0.82 \mathrm{~nm}$, 无法进入分子篮 内部, 只能测得分子篮外部的酸量. 另外, 结合ICP-MS
元素分析可以给出酸中心的定量信息.

为了深入理解稀土改性 $\mathrm{Y}$ 型分子篎的酸性, 本文采 用结合探针分子的 ${ }^{31} \mathrm{P}$ MAS NMR技术, 对分子笁酸中心 的数量、强度以及酸中心分布等进行了详细分析.

\section{2. 实验部分}

\section{1. 样品的制备}

稀土改性Y分子篮采用离子交换法制备. 首先将 $\mathrm{NaY}$ 分子篮 $(\mathrm{Si} / \mathrm{Al}=2.5)$ 用 $\mathrm{NH}_{4} \mathrm{Cl}$ 交换得到 $\mathrm{NH}_{4} \mathrm{Y}$, 然后用 不同浓度的 $\mathrm{RECl}_{3}(\mathrm{RE}=\mathrm{La}, \mathrm{Ce})$ 溶液在 $90{ }^{\circ} \mathrm{C}$ 交换 $2 \mathrm{~h}$ 得 到 $\mathrm{NH}_{4} \mathrm{REY}$, 于 $500^{\circ} \mathrm{C}$ 焙烧 $5 \mathrm{~h}$. 所得样品用去离子水洗 涤, 干燥, $400^{\circ} \mathrm{C}$ 焙烧 $2 \mathrm{~h}$, 得到稀土改性的 $\mathrm{Y}$ 分子篮样品, 记为 REHY $x$, 其中 $x$ 代表 $\mathrm{RE}_{2} \mathrm{O}_{3}$ 的质量分数(但不是其准 确数值).

\section{2. 样品的表征}

固体NMR实验于室温在Bruker MSL-500P仪器上进 行. ${ }^{31} \mathrm{P}$ MAS NMR采用 $4 \mathrm{~mm}$ 双共振魔角旋转探头, 共振 频率 $202.46 \mathrm{MHz}$, 单脉冲程序, 脉冲间延迟 $10 \mathrm{~s}$, 脉冲宽 度 $1.8 \mu \mathrm{s}$, 在 $12 \mathrm{kHz}$ 高速旋转下采集样品 ${ }^{31} \mathrm{P}$ MAS NMR 谱. ${ }^{27} \mathrm{Al}$ MAS NMR实验共振频率为 $130.32 \mathrm{MHz}$, 脉冲间 延迟 $500 \mathrm{~ms}$, 脉冲宽度 $1.0 \mu \mathrm{s}$, 在 $12 \mathrm{kHz}$ 高速旋转下采集 样品谱图. 为了得到良好的谱图信号比, 重复累加多次 扫描, 以 $85 \% \mathrm{H}_{3} \mathrm{PO}_{4}$ 水溶液作为化学位移参考点 $(\delta=0)$.

进行 ${ }^{31} \mathrm{P}$ MAS NMR实验前, 样品需经预处理 ${ }^{[11]}$. 首 先在高真空状态 $\left(133.32 \times 10^{-5} \mathrm{~Pa}\right) 350{ }^{\circ} \mathrm{C}$ 下加热脱水处 理 $24 \mathrm{~h}$, 然后置于氮气袋中冷却至室温; 为了吸附磷氧 化物, 在氮气袋中将一定量的磷氧化合物 (TMPO或 
$\mathrm{TBPO}$ )溶解在无水的二氯甲烷溶液中, 透过密闭性注射 器转移到除水后的样品中; 将上述步骤处理后的混合物 置于超声波振荡槽中振荡 $30 \mathrm{~min}$, 以确保系统达到均匀 饱和吸附; 之后采用液态氮重复冷凝-抽除法, 将多余的 二氯甲烷溶液除去, 再将样品加热至 $140{ }^{\circ} \mathrm{C}$ 维持 $1 \mathrm{~h}$, 使 磷氧化合物分子充分扩散到分子篮样品孔洞中; 最后于 氮气袋中, 将样品转移到 $\mathrm{ZrO}_{2}$ MAS NMR转子中, 并用 Kel-F盖子紧密地封口, 进行 ${ }^{31}$ P MAS NMR实验.

为了确定样品中探针分子在酸性位上的吸附量, 本 实验采用ICP(Jarrell-Ash, ICAP 9000)元素分析方法进行 测定. 将大约 $0.1 \mathrm{~g}$ 的已吸附探针分子样品, 溶解在 10 $\mathrm{mL}$ 含 $\mathrm{HF}, \mathrm{NH}_{3}$ 和 $\mathrm{HCl}$ 的混合溶液中, 然后将 $60 \mathrm{~mL}$ 硼酸饱 和溶液于室温下加入上述混合溶液中, 此混合溶液使用 PET塑料瓶盛装避免外露, 由各自商业化标准测定样品 中 $\mathrm{Si}, \mathrm{Al}$ 和P含量.

吡啶-红外光谱(Py-IR) 分析 ${ }^{[12]}$ 利用 Thermo Nicolet NEXUS 750型FT-IR仪测定样品的表面酸性, 将样品采 用自支撑片法在1.5-2.0 MPa压力下压制成直径 $15 \mathrm{~mm}$ 的圆形均匀薄片, 放置于石英原位池中, 加热到 $450{ }^{\circ} \mathrm{C}$, 并抽真空到 $10^{-3} \mathrm{~Pa}$ 下净化 $2 \mathrm{~h}$. 将样品降至 $90{ }^{\circ} \mathrm{C}$, 饱和吸 附吡啶 $20 \mathrm{~min}$. 然后程序升温, 分别在 200 和 $350^{\circ} \mathrm{C}$ 下高 真空脱附 $20 \mathrm{~min}$, 测定各温度点的红外吸附光谱, 波数范 围4000-900 $\mathrm{cm}^{-1}$.

采用PHILIPS 公司的X'Pert型X射线粉末衍射仪表 征样品的晶体结构. 采用美国Micromeritics 公司ASAP $2405 \mathrm{~N} \mathrm{~V} 1.01$ 型自动吸附仪, 低温静态氮吸附容量法, 在 $-195.6{ }^{\circ} \mathrm{C}$ 下测定样品的吸附-脱附等温线. 根据BET公 式计算样品的比表面 $\left(S_{\mathrm{BET}}\right)$, 测定相对压力 $p / p_{0}=0.98$ 时 样品吸附 $\mathrm{N}_{2}$ 的体积, 将其换算为液氮体积, 即总孔体积. 根据t-plot法计算微孔表面积 $\left(S_{\text {Micro }}\right)$ 和微孔体积 $\left(V_{\text {Micro }}\right)$.

\section{3. 结果与讨论}

\section{1. 稀土改性 $Y$ 型分子篮酸中心的识别}

图1为REHY-8样品分别吸附 TMPO和TBPO探针分 子的 ${ }^{31} \mathrm{P}$ MAS NMR谱图. 由于各稀土改性Y分子篎样品 的 ${ }^{31} \mathrm{P}$ MAS NMR 谱图相似, 本文以REHY-8样品为例进 行谱图解析. 图中虚线为高斯线型模拟方法对重叠谱线 进行分峰拟合的结果，在谱峰形状的基础上,采用 Win-NMR软件程序(Bruker Biospin)进行分峰拟合, 使拟 合光谱与实际观测光谱尽可能重合. 从图 1 可以看出, REHY-8/TMPO样品在 $\delta=78,70,65,62,58,55,53,49$ 和 41 处存在共振谱线, $\delta=49$ 和 41 处特征峰为物理吸附在
分子篮表面的 TMPO分子 ${ }^{[13]}$, 其它共振峰为 TMPO吸附 在不同酸性位的共振谱线. Zhao等 ${ }^{[14]}$ 总结了 $\mathrm{TMPO}$ 在各 种常见固体酸上的 ${ }^{31} \mathrm{P}$ 化学位移值, 吸附在 $\mathrm{L}$ 酸上的 $\delta=$ 60-65. 而 Mueller 课题组 等 ${ }^{[15]}$ 将 $\delta=63$ 处峰归属为 TMPO吸附在分子耖B酸位上的信号.

为了进一步区分 $\mathrm{B}$ 酸中心和Lewis $(\mathrm{L})$ 酸中心, 本文 将REHY-8/TMPO样品置于盛有饱和 $\mathrm{NaCl}$ 水溶液的密闭 容器中, 进行不同时间的吸水实验, 所得样品的 ${ }^{31} \mathrm{P}$ MAS NMR谱图和数据分别列于图2(a)和表 2. 通常认为, L酸 中心容易与水分子作用生成B酸中心 ${ }^{[16]}$; 而 $\mathrm{B}$ 酸中心与 TMPO分子之间存在较强的氢键作用, 在水分子作用下 很难水解, 因此只有与 $\mathrm{L}$ 酸相关的 ${ }^{31} \mathrm{P}$ 谱峰随着水合时间 的增长会显著减弱. 结合上述分析可见, $\delta=55$ 处谱峰由 于随着吸水时间的增长而显著降低, $\delta=78$ 处谱峰随着 吸水时间增长也略有降低, 所以将 $\delta=55$ 和 78 处谱峰归 属于L酸中心与 $\mathrm{TMPO}$ 的作用, 而 $\delta=70,65,62,58$ 和 53 处谱峰归属于B酸中心与 TMPO的作用.

当REHY-8样品吸附TBPO后, 其 ${ }^{31}$ P MAS NMR谱图 在 $\delta=50,76$ 和 86 处存在 3 个明显的谱峰(图1), $\delta=50$ 处吸 收峰为物理吸附在Y型分子篎表面的 TBPO分子, 也可能 含有部分结晶状TBPO吸收峰 $(\delta=47), \delta=76$ 和 86 处吸收 峰归属于 $\mathrm{TBPO}$ 分子吸附在样品不同酸性位的谱峰. 为 了进一步确认 TBPO探针分子与分子篮外表面B酸或 $\mathrm{L}$ 酸相互作用的化学位移, 本文将吸附 TBPO 分子的 REHY-8样品进行不同时间的水合实验, 结果见图2(b)和 表3. 可以看出, $\delta=86$ 处谱峰随着吸水时间的延长逐渐 减弱, $\delta=76$ 处谱峰的相对含量没有降低, 反而略有增加. 由于 $\mathrm{L}$ 酸中心会和水生成B酸中心, 所以本文将 $\delta=86$ 处 谱峰归属于 TBPO和L酸中心的相互作用, 而 $\delta=76$ 处谱 峰归属于TBPO与B酸中心的相互作用.

TMPO分子检测的是分子笁内部和外部酸中心的总 和, 而TBPO只能检测分子篎外部酸中心, 二者的关联可 以识别分子篮内部和外部酸中心的位置、强度、分布及 数量 ${ }^{[11]}$.

已有研究表明, 相对于结晶分子特征峰的化学位移, 尽管所吸附的探针分子不同, 但在同一酸性中心上, 其 特征峰位移的改变程度基本相同 $(\Delta \delta \pm 3)^{[16]}$ : 即以结晶 状TMPO $(\delta=39)$ 和TBPO $(\delta=47)$ 的化学位移作为参考, 化学位移差 $(\Delta \delta)$ 接近的谱峰反映了同一类型的酸位, 即 具有相似的酸强度. 可以推断, REHY-8/TBPO中 $\delta=86$ 和76处特征峰分别对应于REHY-8/TMPO中 $\delta=78$ 和 70 处特征峰, 由于REHY-8/TBPO中特征峰对应分子篎外 
部酸中心, 所以REHY-8/TMPO中 $\delta=78$ 和 70 处特征峰含 有一部分外表面酸性中心, 酸性强, 可能位于分子篮孔 口处, 因为此处结构的不规则或缺陷而存在一些静电作 用. 同样, REHY-8/TMPO 中 $\delta=65,62,58,55$ 和 53 处特 征峰的 $\Delta \delta$ 值分别为 $26,23,19,16$ 和 14 , 在REHY-8/TBPO 谱图中未发现, 所以这些特征峰归属于分子篮内部酸中 心, 其中 $\delta=65,62,58$ 和 53 处谱峰为分子篮内部B酸中 心, $\delta=55$ 处谱峰为分子笁内部L酸中心.

\section{2. 稀土改性 $Y$ 型分子篮酸性的定量分析}

图3 给出了稀土改性Y分子篮分别吸附 TMPO 和 TBPO探针分子的 ${ }^{31}$ P MAS NMR谱图. 可以看出, 随着 稀土含量的增加, REHY分子篮吸附探针分子后的谱图 相似, 没有出现新的特征峰, 但相同位移处谱峰的面积 发生了变化(表4和表5).

分子笁酸性的定量信息需要配合ICP实验分析, 获 得分子篮的总酸量(一个酸中心吸附一个 TMPO分子), 再利用高斯拟合后的谱图计算各个峰面积, 可得每个峰 的面积百分比 (与酸中心相关的峰面积之和为 $100 \%$ ), 将 分子篮上的总酸量与每个峰的面积百分数相乘, 即得酸 中心含量. 表4为REHY分子笁 ${ }^{31} \mathrm{P} \mathrm{NMR} / \mathrm{TMPO}$ 谱图各化 学位移归属及酸中心分布数据, 表 6 为改性 $Y$ 分子笁酸中 心分布图.

随着稀土含量的增加, 分子篮的总酸量呈下降趋势, 当稀土含量较高时, 总酸量下降更显著. 例如, REHY-4, REHY-8, REHY-14 和 REHY-28 的总酸量分别为 2.09 , $2.04,1.93$ 和 $0.99 \mathrm{mmol} / \mathrm{g}$. 其中 L酸中心数量随着稀土含 量增加一直减少; 而 $\mathrm{B}$ 酸中心数量的变化不象 $\mathrm{L}$ 酸那样 显著, 只有当稀土含量较高时 $\mathrm{B}$ 酸中心含量才显著降低.

酸强度分布方面, 当稀土含量低于 $14 \%$ 时, 稀土有 利于中等强度B酸中心(吸附 TMPO时 $\delta=62$ 和 58 ) 数量显 著增加, 较弱 $\mathrm{L}$ 酸中心数量(吸附 $\mathrm{TMPO}$ 时 $\delta=55$ ) 显著下 降, 强 $\mathrm{B}$ 酸中心(吸附 $\mathrm{TMPO}$ 时 $\delta=65$ ) 数量减少; 当稀土 含量较高时(如REHY-28), B酸中心的数量显著减少.

酸位置分布方面, 分子篮外表面酸中心仅占分子篎 总酸量的 $5 \%-10 \%$, 且主要由强酸组成; 分子篮酸中心 主要存在于分子笁孔洞内, 约占总酸量的 $90 \%$ 以上, 且 酸强度分布范围较广 (从强酸到弱酸都有).

本文还利用吡啶吸附红外光谱(Py-IR)方法对分子 篮酸中心种类及数量进行了表征. 吡啶是检测固体样品 酸类型比较合适的探针分子, 易与 $\mathrm{B}$ 酸作用生成 $\mathrm{PyH}^{+}$, 其 $\mathrm{C}-\mathrm{C}(\mathrm{N})$ 键伸缩振动的红外特征吸收峰出现在 $1540 \mathrm{~cm}^{-1}$ 附近, 同时 Py 还可与 L 酸发生配位生成Py-L, 在 1450 $\mathrm{cm}^{-1}$ 附近出现 $\mathrm{C}-\mathrm{C}(\mathrm{N})$ 键伸缩振动吸收峰. 对于 $\mathrm{Y}$ 型分 子篮而言, 由于Py的动力学直径较大, 只能进入分子篮 大笼与羟基发生作用, 而不能进入较小的笼与羟基发生 作用, 因此Py-IR法测得的酸性主要是Y型分子篮外表面 和超笼中的酸性.

图4给出了分子篎酸量随稀土含量的变化趋势. 可 以看出, 在总酸量方面, 随着稀土含量的增加, 分子篮的 总酸量下降, 尤其是 $L$ 酸中心数量随着稀土含量增加一 直减少, 而 $\mathrm{B}$ 酸中心的数量只有当稀土含量较高时才显 著降低. 这与探针分子的 ${ }^{31} \mathrm{P} N \mathrm{NMR}$ 分析结果一致. 然而, Py-IR分析不能给出不同强度酸中心的分布以及位置等 详细信息, 存在一定的局限性.

\section{3. 稀土对Y分子篮酸性的影响}

通过XRD及 ${ }^{29} \mathrm{Si}$ MAS NMR 分析发现, 随着稀土含 量增加, 分子篎晶胞常数增大, 骨架 $\mathrm{Si} / \mathrm{Al}$ 比降低, 骨架 $\mathrm{Al}$ 数量增加, 表明稀土的引入能显著抑制分子篮晶胞常数 收缩, 避免骨架铝脱除. 以前的研究借助于量子力学密 度泛函理论进行了计算, 进入分子篮 $\beta$ 笼中的稀土离子 与分子筛骨架 $\mathrm{O} 2$ 和 $\mathrm{O} 3$ 原子较好地配位成键, 增加了骨 架铝原子的稳定性, 抑制了非骨架铝物种的形成 ${ }^{[17]}$.

结合骨架A1、非骨架A1以及稀土离子对分子篮酸性 的影性, 建立了以下机理模型(图5). (1) 采用液相离子 交换法制备稀土改性 $\mathrm{Y}$ 型分子篮时, $\mathrm{RE}^{3+}$ 对其周围的 $\mathrm{H}_{2} \mathrm{O}$ 产生极化和诱导作用, 有效吸引 $\mathrm{H}_{2} \mathrm{O}$ 中 $\mathrm{OH}^{-}$生成 $\mathrm{RE}(\mathrm{OH})^{2+}{ }^{218]}$, 在热处理条件下, $\mathrm{RE}(\mathrm{OH})^{2+}$ 可以由分子篮 超笼迁移进 $\beta$ 笼 $I^{\prime}$ 位; 进入分子笁 $\beta$ 笼 $I^{\prime}$ 位的 $R E(O H)^{2+}$ 与 $\mathrm{O} 2$ 和 $\mathrm{O} 3$ 相互作用, 增强了 $\mathrm{Al}-\mathrm{O}$ 作用力, 稳定了分子篮骨 架结构, 提高了分子笁的水热稳定性. (2) 在酸中心强度 方面, 在热或水热处理条件下, 分子篮骨架 $\mathrm{Al}$ 易脱除生 成非骨架 $\mathrm{Al}$ 物种, 非骨架 $\mathrm{Al}$ 物种的生成和骨架 $\mathrm{Al}$ 数目的 减少导致脱铝后 $\mathrm{Y}$ 分子篎(USY分子篮)的B酸强度显著 增大 ${ }^{[19,20]}$; 由于以 $\mathrm{RE}(\mathrm{OH})^{2+}$ 形式进入分子筷 $\beta$ 笼 $I^{\prime}$ 位的稀 土离子稳定了分子篮骨架结构, 抑制了骨架 $\mathrm{Al}$ 的脱除, 减少了非骨架 $\mathrm{Al}$ 物种的生成, 所以稀土改性Y型分子篮 的B酸强度低于USY分子篮的; 同时, 稀土离子与分子 笁骨架 $\mathrm{O} 2$ 和 $\mathrm{O} 3$ 的相互作用, 使分子篎骨架 $\mathrm{O} 1$ 负电荷减 弱, $\mathrm{Al}-\mathrm{O} 1$ 键长变短, $\mathrm{H}^{+}$释放能力增强, 所以与 $\mathrm{HY}$ 分子篮 相比, 稀土改性 $\mathrm{Y}$ 型分子笁的B酸强度增加, 即分子篮B 酸中心强度顺序如下: USY $>$ REHY $>$ HY. (3) 在酸中 心数量方面, 通过 $\mathrm{NH}_{4}{ }^{+}$交换 $\mathrm{NaY}$ 中 1 个 $\mathrm{Na}^{+}$并脱除 $\mathrm{NH}_{3}$ 后 生成的HY分子篎具有较多的B酸中心, 经过热或水热处 理后生成USY分子篮, 骨架Al的脱除导致USY分子篮具 
有较少的 $\mathrm{B}$ 酸中心数量; 对于稀土改性 $\mathrm{Y}$ 型分子篮, $\mathrm{RE}^{3+}$ 水解产生的 $\mathrm{RE}(\mathrm{OH})^{2+}$ 可以进入 $\mathrm{NaY}$ 分子篮 $\beta$ 笼交换 2 个 $\mathrm{Na}^{+}$, 同时水解产生的 $\mathrm{H}^{+}$交换超笼中 1 个 $\mathrm{Na}^{+}$, 进一步经过 $\mathrm{NH}_{4}{ }^{+}$交换和脱除 $\mathrm{NH}_{3}$ 后生成REHY分子節, 所以 REHY 分子篮的 $\mathrm{B}$ 酸中心数量比 $H Y$ 分子筛的少 ${ }^{[21]}$; 又由于 $\beta$ 笼 中 RE $(\mathrm{OH})^{2+}$ 对分子篮骨架结构的稳定作用, 避免了骨架 $\mathrm{Al}$ 的脱除, 所以 REHY 分子篎的B酸中心数量比USY 分 子篮的多, 即分子篮 $\mathrm{B}$ 酸中心数量顺序如下: $\mathrm{HY}>$ REHY $>$ USY.

因此, 随着稀土含量的增加, 分子篎强B酸中心和较 弱 $\mathrm{L}$ 酸中心的数量显著降低, 而中等强度 $\mathrm{B}$ 酸中心数量显 著增加.

\section{4. 结论}

分别以 TMPO和TBPO为探针分子的 ${ }^{31}$ P MAS NMR
实验配合ICP元素分析探测了稀土改性Y型分子篮的酸 性. 结果表明, $\mathrm{Y}$ 型分子篎存在 5 种 $\mathrm{B}$ 酸中心和 2 种 $\mathrm{L}$ 酸中 心, 其中 4 种强度不同的 $\mathrm{B}$ 酸中心和 1 种较弱的 $\mathrm{L}$ 酸中心位 于分子篮内表面, 分子篮外表面存在 2 种较强的酸中心. 随着稀土含量的增加, $\mathrm{Y}$ 型分子篎中的强 $\mathrm{B}$ 酸中心和较 弱 $\mathrm{L}$ 酸中心数量显著降低, 而中等强度 $\mathrm{B}$ 酸中心数量显著 增加, 当稀土含量过高时, 分子篮的总酸量显著降低. 与 传统酸性表征方法相比, 结合多种探针分子的固体核磁 共振技术更能全面认识分子笛的酸性, 即酸类型、酸强 度、酸量以及酸位分布.

\section{致谢}

本工作主要在台湾 “中央” 研究院原子与分子科学 研究所完成, 得到刘尚斌教授的大量指导, 在此表示诚 挚的感谢. 